\title{
NARRATIVAS DA VIOLÊNCIA: A DIMENSÃO MICROPOLÍTICA DAS EMOÇÕES*
}

Maria Claudia Coelho

\section{Introdução}

Este artigo discute a relação entre moral, alteridade e violência, tendo como objeto de análise os sentimentos presentes em relatos de experiências de vitimização em uma modalidade específica da violência urbana: os assaltos a residências. Insere-se na área de investigação da antropologia das emoções, tomando como vertente teórica o "contextualismo" (Lutz \& Abu-Lughod 1990), com sua ênfase na dimensão micropolítica das emoções.

O universo analisado são as camadas médias do Rio de Janeiro. A metodologia utilizada é a entrevista em profundidade. Os dados são um conjunto de oito entrevistas realizadas com três casais que vivenciaram juntos, marido e mulher, experiências de assaltos às suas residências; e com duas mulheres que tiveram também suas residências assaltadas enquanto estavam em casa, em companhia de seus maridos e/ou filhos, empregados etc. ${ }^{1}$ Os três homens entrevistados têm 84, 55 e 43 anos; suas esposas têm, respectivamente, 85, 52, e 42 anos. As outras duas mulheres têm 66 e 50 anos. Todos têm filhos: o primeiro casal tem dez, o segundo tem dois e o terceiro tem um; as duas mulheres têm, cada qual, dois filhos. O primeiro casal reside em um bairro de camadas médias da zona norte da cidade, o segundo, na zona sul do Rio de Janeiro e o terceiro, na Barra da Tijuca. As duas mulheres residem em bairros da zona sul do Rio de Janeiro. Entre os homens, há um funcionário público aposentado, um engenheiro e um gerente de empresa multinacional; entre as mulheres, há três donas de casa, uma marchand e uma pequena empresária.

O texto busca explorar a existência de uma narrativa-padrão nestas experiências, com foco na caracterização dos assaltantes e nos sentimentos por eles suscitados nos entrevistados. Para tanto, está estruturado em três seções. Na primeira delas, exponho os pressupostos teóricos que nortearão a análise, em particular: a) principais vertentes da antropologia das emo- 
ções, seguindo o mapeamento proposto por Lutz \& Abu-Lughod (1990); b) a existência de uma dimensão micropolítica das emoções, ou seja, a capacidade que as emoções têm de atualizar, na vivência subjetiva dos indivíduos, aspectos de nível macro da organização social.

A segunda seção examina os relatos dos entrevistados, enfocando o exame das representações que fazem dos assaltantes, com ênfase em suas atitudes e atributos, procurando rastrear as associações entre "desordem", "sujeira", "pobreza" e "ignorância". A terceira parte aborda os sentimentos suscitados pela experiência de vitimização entre os entrevistados, procurando delinear a existência de uma dinâmica entre humilhação/medo/impotência, de um lado, e raiva/desprezo/compaixão, de outro.

\section{A emoção como objeto das ciências sociais: um esboço do campo}

O campo da antropologia das emoções conheceu um forte desenvolvimento nos Estados Unidos a partir de meados da década de 1980, com a publicação de um texto hoje referência obrigatória destes estudos: o trabalho de Michelle Rosaldo (1984) sobre a influência da perspectiva interpretativista de Clifford Geertz sobre o estudo antropológico dos afetos. ${ }^{2}$

Com base em diversas comparações de cunho etnográfico com material obtido em trabalho de campo junto aos Ilongot, a autora formula como tarefa da antropologia mostrar de que modo a cultura (em sua dimensão pública e simbólica) interfere na experiência psicológica dos indivíduos. Para a autora, o ponto central é "o reconhecimento do fato de que o sentimento sempre recebe sua forma através do pensamento, e de que o pensamento é carregado de sentidos emocionais" (Rosaldo 1984:143, tradução minha). Em uma tentativa de esclarecer a fronteira entre pensamento e sentimento, Rosaldo sugere que a distinção-chave é a forma de envolvimento do self do ator social, extraindo daí sua conhecida formulação do sentimento como um "pensamento incorporado":

As emoções são pensamentos de algum modo "sentidos" em rubores, pulsações, movimentos do fígado, mente, coração, estômago, pele. São pensamentos incorporados, pensamentos perpassados pela preocupação de que "eu estou envolvido". A oposição pensamento/afeto revela assim a diferença entre a mera escuta do choro de uma criança e a escuta sentida - como aquela que ocorre quando percebemos que há perigo envolvido ou que a criança que chora é o seu próprio filho (1984:143, tradução minha). 
Rosaldo conclui então pela afirmação de que os sentimentos são práticas sociais, estruturadas pelas formas de compreensão e concepção do corpo, do afeto e da pessoa, estas por sua vez culturalmente definidas, o que a leva a postular uma desconfiança quanto à suposição da universalidade das emoções (:143).

Esta perspectiva, cuja essência podemos definir como a crença no caráter culturalmente construído das emoções, é também o que orienta as reflexões de Lutz (1988) acerca da concepção euroamericana das emoções, abstraída a partir do esforço de compreensão das emoções ifaluk, em um movimento autorreflexivo típico do empreendimento antropológico. Lutz esboça um minucioso quadro da forma euroamericana de conceber o plano emocional da experiência humana, na qual a oposição-chave seria emoção/pensamento.

Esta oposição surgiria no pensamento euroamericano em diversas versões: no universo acadêmico, sob a forma afeto/cognição; em sua variante romântica, como uma oposição entre razão e paixão; e no senso comum, como sentimento/pensamento. Estes opostos compartilhariam um traço comum: seriam as realidades mais autênticas do indivíduo, os espaços de surgimento do self verdadeiro, mais autênticos do que a fala ou outras formas de interação.

O eixo fundamental em torno do qual a autora elabora esta concepção euroamericana das emoções (aquilo a que chama "etnopsicologia") é um par de termos em relação aos quais a emoção se opõe: o pensamento e o distanciamento do mundo. Quando em relação ao pensamento, a emoção situa-se no polo negativo, sendo o pensamento a forma valorizada; quando em oposição ao distanciamento, a emoção é o polo positivo, o distanciamento sendo algo a ser evitado.

Os trabalhos de Rosaldo e Lutz, em seus esforços de teorização sobre o fenômeno emocional a partir de comparações entre materiais etnográficos distintos, podem ser entendidos como representantes daquela vertente que a própria Catherine Lutz, poucos anos depois, batizaria como corrente "relativista" dos estudos sobre emoção. Nesta corrente, a tônica seria o rompimento com a crença na existência de qualquer aspecto essencial nas emoções, que seriam construtos culturais de natureza evidentemente variável.

Esta corrente relativista integra, juntamente com duas outras formas de estudo das emoções, o mapa das formas de pensar sobre emoção delineado por Lutz \& Abu-Lughod (1990) na introdução a uma coletânea de estudos sobre emoções. As autoras apontam a existência de duas outras correntes: a essencialista - marcada, como o nome sugere, pela convicção de que as emoções são fatos universais, brotando do íntimo da experiência individual 
e refratárias a qualquer configuração sociocultural - e a historicista, que compartilharia com o relativismo a convicção de que as emoções são construtos culturais, entendidos aqui, porém, de uma perspectiva diacrônica.

Lutz \& Abu-Lughod elaboram, contra o pano de fundo deste mapa, a proposta que batizam de perspectiva contextualista, cuja inspiração teórica é a noção de discurso de Foucault, entendido como uma fala que forma aquilo sobre o que fala, ao invés de manter com ele uma relação de referência, como algo que lhe seria externo. Esta perspectiva permite às autoras adentrarem a dimensão micropolítica dos sentimentos, mostrando como as emoções são tributárias de relações de poder entre grupos sociais, servindo simultaneamente para expressar e reforçar tais relações.

Um exemplo desta visão é o próprio trabalho de Lutz (1990) incluído nesta coletânea. Nele, a autora retoma suas reflexões sobre o lugar da emoção no pensamento ocidental, partindo da ideia de que "qualquer discurso sobre emoção é também, ao menos implicitamente, um discurso sobre gênero" (:69, tradução minha). Seu foco neste texto é a existência de uma "retórica do controle" das emoções associada ao gênero, o que, em sua visão, faria com que o discurso sobre as emoções fosse também uma fala sobre o exercício do poder.

Com base em um conjunto de entrevistas realizadas com homens e mulheres norte-americanos pertencentes às camadas médias e populares, Lutz desenvolve então uma análise sobre o modo como o tema do controle das emoções aparece no discurso de homens e mulheres. Seu ponto de partida é um paradoxo que identifica no discurso ocidental sobre as emoções: elas seriam ao mesmo tempo "sinais de fraqueza" e uma "força poderosa". Este paradoxo estaria no cerne da ambiguidade que cercaria a condição feminina no pensamento ocidental: "a emocionalidade é a fonte do valor da mulher, sua expertise ao invés da racionalidade, mas ao mesmo tempo é a origem da sua inadequação para tarefas sociais mais amplas e mesmo uma ameaça potencial a seus filhos" (:77, tradução minha).

Lutz sugere ainda a existência de um paralelo entre esta forma de compreensão da condição feminina e o estudo de Taussig (1984) sobre o colonialismo, em que o autor aponta para a ambiguidade presente na visão dos colonizadores em relação aos indígenas, na qual medo e espanto se alternam com nojo e menosprezo. Para Taussig, este seria um processo em que um "espelho colonial" "reflete de volta para o colonizador a barbárie de suas próprias relações sociais" (Taussig 1984:495 apud Lutz 1990:77, tradução minha). Lutz enxerga nesta comparação a possibilidade de se pensar em um "paradoxo da vontade" como recorrentemente presente nas relações de dominação, 
pois o outro subordinado é ideologicamente representado como fraco (de forma a precisar de proteção ou disciplina) e ainda assim periodicamente como uma ameaça à fronteira ideológica, podendo rompê-la através da insubordinação ou da histeria. A fala sobre a emoção, conforme evidenciado nestas transcrições, mostra as mesmas contradições quanto ao controle, à fraqueza e à força. Dada sua definição como natural, ao menos no Ocidente, os discursos sobre a emoção podem ser um dos mais prováveis e poderosos instrumentos por meio dos quais se exerce a dominação (:77-78, tradução minha).

Este tema das relações entre emoção e poder está no centro de outros estudos produzidos por cientistas sociais de várias tradições intelectuais voltados para a compreensão da dimensão micropolítica de sentimentos específicos, mostrando como a gramática da emergência e da expressão destes sentimentos pode iluminar aspectos de nível "macro" da organização social. Nas próximas seções, buscaremos compreender os sentimentos narrados pelos entrevistados - em particular, a compaixão e o desprezo com base em alguns estudos que visam ao entendimento desta capacidade micropolítica das emoções.

\section{As representações dos assaltantes}

A descrição dos assaltantes realizada pelos entrevistados deixa entrever uma recorrência: a natureza desorganizada e caótica de suas atitudes. Em vários depoimentos, chama a atenção a presença de um retrato da atuação dos assaltantes, tomada coletivamente como "agitada", "desorganizada", uma "bagunça":

Mas eles eram dois primários. Eu tenho a impressão de que eles não eram de [cidade praiana]. Eu tenho a impressão de que eles nessas ondas [...] dessas festas idiotas na beirada da praia, que fazem aquelas coisas, aquela sujeirada toda, aquele murmurinho, todo mundo faz o que quer no meio da rua, é uma bagunça geral nessa época (Rafael). ${ }^{3}$

As nossas portas de armário são de correr. Então a gente só ouvia assim, aquele barulho, ploft, ploft, porque são quatro quartos, ali, e era tudo assim uma barulheira tremenda, depois ouvimos rasgando aqueles lençóis que são tipo náilon, também, que não é algodão puro, e eu dizia assim, "meu Deus, o que será isso?" (Magnólia). 
Aí eu fiquei com raiva, entendeu, deles estarem ali, jogando cigarro no chão, entendeu, fazendo a maior bagunça, rasgando aquelas roupas da gente toda, levando meu casaco que eu adorava, que meu marido tinha me dado na lua de mel... (Joana).

Esta representação dos assaltantes pode eventualmente exceder o plano da "desordem", sendo descrita como "sujeira", como na fala acima de Rafael ou neste diálogo:

Aí demoraram muito. Porque eles inclusive comeram, abriram geladeira, fizeram uma farra geral, uma barulheira tremenda.

Uma imundície, né? (Magnólia e Rafael).

Em outros momentos, quando caracterizados individualmente, uma oposição aparece também com frequência: os "agitados" versus os "calmos", com a "agitação" sendo muitas vezes associada ao uso de drogas. Alguns exemplos:

Mas... é... em termos específicos, eram quatro assaltantes, com uma liderança nítida de um deles, que era um sujeito equilibrado, tanto que entrou armado, logo em seguida, quando viu que a situação tava sob controle, ele se desfez da arma.

Fez o quê?

Deu pro outro, não me lembro mais, mas não ficava armado. E um louco, completamente alucinado, que andava com dois revólveres na mão, trocando de canal usando o cano do revólver, entendeu... (Luís).

O que você lembra deles?

Eles eram superagitados, entre eles, né?

Que idade, mais ou menos?

Ah... eles eram todos bem novos. Um... tinha o chefe, que era o mais arrumado, que inclusive tava muito bem vestido, que era uma pessoa escura, assim, bonitão, magro, não era assim... magro, alto, bonito, um cara bonito... ele era mais tranquilo. Esse que mandava. [...] Eram quatro que eu vi. Ah, eram quatro lá dentro, mas tinha um outro lá fora que eu não sei... eu falei errado, eram cinco assaltantes, tá, na época, mas esses que tavam lá dentro com a gente, eles eram mais agitados, a não ser o chefe. Eles eram agitados, eles fumavam, eles falavam "nós não temos nada a perder", e ficaram rindo, nervosos (Joana). 
E eram três. Dois assim até bem apessoados e tinha o mais velho, parecia tá meio dopado que fosse, ele é muito agitado, e aí eles queriam mais coisas. Disse: "Não! Nós não temos, joias nós não temos nem coisa nenhuma", né? E aí então... Nós vimos que eles estavam mexendo pela casa inteira, né? (Vânia).

Os outros eram muito maus. Eles botavam a arma bem "aqui", enfiavam arma na sua cabeça. Esse não fazia isso, nunca fez. O que fez comigo botou aqui de longe e virou, mas eu senti que ele não tava fazendo aquilo... Ele não ia fazer, era o que me passava. Eu, por algum motivo, senti mais confiança nele. E ele não tava drogado. Um com certeza tava drogado. Os outros dois não. Um era muito calmo (Ana).

Eu acho que o mais agressivo preponderava. [...] O mais organizado falou que se a gente se comportasse tudo ia acabar certo; durante o assalto eles não agiram assim. Entendeu? Então, ele deu a entender que tudo ia... ia ser um assalto tranquilo, mas eles não abriram mão da intimidação, nem das ameaças, nem eu acho que da violência de amarrar, de estar encostando a arma na cabeça. Acho que... Então, acho que a diferença entre eles era de função ali, acho. Personalidade, talvez o mais novo um pouco mais agressivo, né? (Guilherme).

Reproduzi nesta seção a sequência de trechos, retirados dos depoimentos de sete entre os oito entrevistados, para acentuar a recorrência do tema da "desordem" na caracterização dos entrevistados, eventualmente associada à "imundície", em um vínculo simbólico que evoca a clássica concepção da "sujeira" como algo que está "fora do lugar" (Douglas 1976). Esta descrição das atitudes dos assaltantes nos remete também à discussão proposta por Caldeira (2000) sobre a violência como "desordem", identificada de forma clara, em seu universo, em uma estratégia retórica que principia sempre por descrever um cotidiano no qual a violência irrompe subitamente, transtornando-o. ${ }^{4}$

Um segundo traço também muito nítido na caracterização dos assaltantes é sua associação à pobreza:

Todos assim de classe média, só tinha um que era... um pouquinho, talvez uma classe $\mathrm{C}$, assim, mais pobre, mas não era nenhuma pessoa que você pudesse dizer assim: "Não! são pessoas necessitadas, vieram, nasceram é... numa situação muito difícil". Não dava pra perceber isso não, todos eles tinham, vai ver que tinham até educação, reconheceram a gravura do Monet.

Você acha que teria feito diferença pra você assim?

É... assim, teria me surpreendido menos. Eu acho que a diferença foi a surpresa 
de ter percebido que eram pessoas de um nível de educação pelo menos secundário ali. Inclusive, o mandante estudando o nível superior, né? Ele ainda não tinha terminado, mas tava lá. Cursando... Teria sido... Eu teria ficado menos surpreso, mas numa justificativa mais racional. Pô! A pessoa precisa! Mas não era o caso. A diferença seria mais ser surpreendido [pela] expectativa que eu tinha de que as pessoas que roubam são pessoas é... altamente necessitadas, que vieram de uma situação muito difícil, não tiveram nenhuma oportunidade na vida, e o crime seria uma consequência racional dessa... desse meio ambiente em que elas viviam, né? $\mathrm{O}$ que não me pareceu em nenhum momento ser o caso deles, né? Um deles, inclusive, tinha, morava praticamente ali [na rua de moradias de alto luxo] e tal (Guilherme).

A fala de Guilherme explicita uma expectativa que nos demais depoimentos aparece de forma sub-reptícia: a vinculação da criminalidade à pobreza, com a privação material sendo concebida como motivação fundamental para a decisão de assaltar. Esta associação aparece de forma mais sutil em outros relatos, eventualmente vinculando pobreza, criminalidade e "favela" ou "subúrbios", em uma relação de resto já tantas vezes estabelecida no senso comum de segmentos das camadas médias e altas da população carioca:

[...] era uma quadrilha de classe média alta. Quer dizer, dois eram de classe média alta. Nenhum era favelado, os outros dois eram... classe média... um classe média baixa o outro pobre, mas nenhum deles morava em favela. [...] esse era o único pretinho da situação, e o outro até era mulato, o outro que estava lá embaixo; um deles era [mulato] e o outro era branco. E... um era da [rua de moradias de alto luxo] (Ana).

[...] o meu medo é que eu me via assim, jogada, num subúrbio aí qualquer da vida, estuprada, levando tiro, ou morta. Eu visualizava na minha cabeça: eu já era jogada num buraco aí qualquer... (Joana).

Esta associação entre violência e diferenças de classe social surge nos depoimentos ainda de outra maneira, esta bem mais sutil: as especulações quanto às razões por que suas residências teriam se tornado alvo do interesse dos assaltantes. Em vários relatos, os entrevistados supõem, por mínimos indícios, que pessoas que haviam prestado serviços em suas residências sintomaticamente, serviços de baixas qualificação profissional e remuneração, tais como faxina, jardinagem ou construção - haviam, intencional ou inadvertidamente, passado informações a conhecidos seus do mesmo meio 
social (definido pelo nível de renda e/ou pelo local de moradia), suscitando assim uma "cobiça" que os teria tornado alvo dos assaltantes. Exemplos desta lógica:

Porque esse rapaz que era faxineiro, ele tinha entrado de férias e naquele dia tinha começado um rapaz para ficar um mês, que a síndica simplesmente contratou o rapaz sem nem ver, [...] ninguém via que o rapaz saía, ninguém conhecia, ninguém tinha visto. A gente imagina que talvez tivesse alguma coisa com ele. Só podia ser, né? (Vânia).

Enquanto o outro [outro assalto que sofrera], eu sabia que eles tinham estudado a casa da gente, eles sabiam que devia ter coisa lá, eu achava que tinha papo de empregada, porque empregada adora contar que a patroa tem mais do que a outra patroa. Deve ter falado alguma coisa [...] porque tinha uma empregada que trabalhava lá em casa, [...] que era muito deslumbrada... entendeu? Então eu achei que lá, na casa da mamãe, eles sabiam que tinha alguma coisa (Joana).

Houve uma coisa... nós tínhamos feito uma obra muito grande na casa, e foi contratado um... como é que se diz?... mestre de obras. E nós estávamos aqui e a caseira ficou lá. Então, a caseira disse que a casa estava cheia de gente na limpeza, que foi limpeza geral, pintura por dentro, por fora, aquela coisa, né? E a caseira dizia: "ah, esses dois rapazes, eu acho que trabalharam aqui, porque o tipo de corpo que eles tão apresentando era dos rapazes que andavam por aqui". Mas nós não temos nenhum conhecimento ou certeza disso agora (Magnólia).

E ainda teve outro problema: nós chamamos um homem pra tirar coco, porque nós temos uns coqueiros lá em casa. E esse senhor levou um garotão de uns 13 anos, mas um anão, mas de 13 anos pra ajudar a carregar as folhas de coco, aquela coisa toda. E acontece que nosso cachorro ficou solto no quintal na presença deles, porque o cachorro era muito obediente, é só a gente chamar, ele atende e tal. E num determinado momento... primeiro, o Rafael tem o hábito de botar o dinheiro no bolso sem carteira, sem coisa nenhuma. E se ele tem que pagar, seja táxi, seja pra tirar o ofertório da igreja, seja pra fazer qualquer pagamento, ele mete a mão, puxa aquele bolão de dinheiro e fica catando. O homem do coqueiro viu quando ele foi pagar, o menino viu. E houve um determinado momento em que não sei quem falou qualquer coisa sobre o cachorro e esse garoto disse: "ah, esse cachorro não é de nada". Então, nós ficamos com aquele problema de que [na casa estavam] o casal de velhos, um cachorro que não é de nada e o homem que tinha dinheiro no bolso. [Isto] deve ter corrido... 
quer dizer, isso é um pensamento meu, tá? E conversei também com alguns filhos e todos eles acham que realmente pode ter havido um... não que esses tenham ido lá em casa, mas podem ter comunicado a esses outros lá do [nome de bairro da cidade praiana], que têm qualquer coisa com a Baixada...

Esse bairro é o quê, um bairro de classe média?

Não, não. Meio, tem muita... algumas favelas.

Mais necessitado.

É, tem comércio...

Muito comércio.

Mas é uma classe média bem, bem pra baixo e outras... (Magnólia e Rafael).

Este tipo de explicação para esta modalidade de violência, associada a uma clivagem entre classes sociais, opera assim com uma associação entre criminalidade, pobreza e local de moradia, sendo particularmente nítido neste último depoimento, em que o casal imagina a existência de uma rede de contatos entre pessoas moradoras de um bairro onde há "favelas", em uma cidade praiana e a Baixada Fluminense, que teriam tido acesso à informação de uma suposta "riqueza" a eles atribuída através de um prestador de serviços de jardinagem. Esta lógica parece aproximar estes depoimentos do discurso de tipo "despótico" sobre a violência, segundo tipologia proposta por Soares e Carneiro (1996), o qual, entre outras características, postularia a existência de focos urbanos de violência, identificados primordialmente com as favelas.

O terceiro e último traço marcante na representação dos assaltantes é a ignorância a eles atribuída pelos entrevistados. Esta ignorância, contudo, não é explicitada da mesma forma que a pobreza, a bagunça ou a sujeira, não sendo nomeada, porém sugerida em comentários depreciativos, eventualmente irônicos, feitos en passant:

Agora, que eles venderam, devem ter vendido por qualquer coisa... devem ter vendido, porque tem coisas que valem e tem coisas que nem valem, né? Ainda mais eu que mexo com esses troços, de antiguidades, até de joia, não sei o quê... Às vezes você olha num casamento, as mulheres todas de joias maravilhosas; tem umas que valem muito, tem umas que não valem nada, mas têm o mesmo efeito da outra, é um brilhante que tem um carvão, o outro não tem...

Você acha assim que venderam por qualquer coisa por desconhecimento do valor, por não saberem onde vender..

Eu acho que por desconhecimento de valor e também porque eles têm que se sujeitar a vender pra negociantes que não são bons negociantes, que são 
pessoas que são ladras também, e que vão comprar, que vão ganhar dinheiro em cima deles (Joana).

Cada coisa que eu me lembrava que eu tinha eu dava graças a Deus. E algumas eles queriam e outras não, né? Então... Se encantavam com bobagens, por exemplo, uma mochila da [nome de loja], uma bolsa de viagem. Ninguém viu porque o Guilherme usava aquilo uma vez na vida outra na morte. Acharam aquilo lindo e maravilhoso, levaram. E outras coisas que havia, que talvez tivessem até mais valor, eles não levaram, tipo um relógio da [nome de marca], de ouro.

Não viram?

Viram, eu dei, mas eles não quiseram, não entenderam, então... (Ana).

Ah, tem uma coisa interessante, na hora que me coube ir ao meu quarto pra mostrar as minhas coisas, eu pude então avisar que havia arma - eu tinha um revólver que ficava assim debaixo da cama, no meu lugar, do meu lado. Aí eu mostrei o revólver, apontei, ele foi lá, pegou; nessa altura estávamos eu e ele no quarto, um de cada lado da cama, da minha cama. Ele então pegou o meu revólver, botou no meio da cama e disse assim: "vamos ver quem é mais rápido", o dele no cinto, preso à calça. E eu disse: "não, não vou fazer isso, isso não é meu métier". Depois me arrependi, porque tive que explicar pra ele o que era métier, entendeu? (Luís).

Aí eles começaram a remexer nas coisas, pegaram minha carteira de identidade. Eu era funcionário naquela época e tinha uma carteira especial. Eu disse "eu tô perdido". Mas eles eram analfabetos, felizmente. De modo que ele olhava, olhava, olhava a carteira e dizia "você deve ser daqueles que fala[m] com o [presidente do Brasil] na hora que quer" (Rafael).

Estas passagens permitem entrever um esforço de demarcação de superioridade, aqui acionado em relação a um nível cultural representado como inferior: os assaltantes são analfabetos, com vocabulário limitado e incapazes de reconhecer o valor das próprias coisas que desejam roubar. Este esforço sugere haver um traço de desprezo dos entrevistados pelos assaltantes sentimento este que nos conduz à próxima seção deste trabalho.

\section{Os sentimentos dos entrevistados}

Os depoimentos são permeados por expressões relativas às experiências emocionais dos entrevistados durante os assaltos. O desprezo, insinuado 
nestas passagens que aludem a uma suposta "ignorância" dos assaltantes, é mais explícito em outros momentos, em particular aqueles nos quais os entrevistados fazem comentários em que acentuam sua superioridade em termos de condição econômica.

[...] ele disse pra mim [imita tom impositivo]: "me dá o celular!". Aí, eu, pra não ficar sem telefone, ele não tinha me revistado, peguei o celular no bolso, entreguei a ele. Um celular lindo. Presente dela pra mim. Agora eu tenho um que é uma porcaria. Ótimo. Quando eu der esse celular pra um bandido, ele vai dizer, "Coitadinho. Doutor, fica com ele" [risos]. "Não quero isso não" (Rafael).

A única coisa que eles levaram da [filha] foi o chip do celular, só! Pra gente não poder se comunicar. Eles: "O celular dela é bem pior do que o meu!". Aí, o Guilherme, nessa hora a gente pensou, eu pensei cá com os meus botões: "O meu é comprado, o teu é roubado, mas tudo bem!" (Ana).

[...] eles diziam assim: "É! Esse pessoal aí, esse prédio de classe média, esse pessoal não tem nada mesmo!". Eu falei assim: "É! não tem nada não, meu filho. Meu marido é funcionário público. O que um funcionário público ganha? Se você tá querendo assaltar lugar de dinheiro, você vai procurar lugar que tenha gente de dinheiro; aqui no prédio todo mundo é assim do mesmo jeito, todo mundo é duro. Você não vai encontrar nada de um milhão por aqui". Eu falava pra ele [gargalhadas] (Vânia).

A forma irônica com que os entrevistados relatam esses momentos dos assaltos, seus diálogos internos, a jocosidade sugerem a existência de uma espécie de regozijo neste proclamar-se detentor de pouco. É assim que Rafael ri ao imaginar a "pena" que o assaltante teria dele ao ver a baixa qualidade de seu celular; Ana replica, em um diálogo interno, a observação do assaltante também quanto à má qualidade de seu celular, acentuando que tivera meios próprios para adquiri-lo; e Vânia se deleita ao reproduzir a conversa em que informa ao assaltante não possuir nada de valor.

Mas de que modo o declarar-se detentor de pouco ou menos do que o outro pode estar a serviço de uma afirmação de um lugar hierarquicamente mais elevado? Enfatizo o "declarar-se" porque é evidente, por outras passagens dos depoimentos (inclusive aquelas citadas acima sobre a representação dos assaltantes como "pobres"), que a percepção dos entrevistados acerca das diferenças de poder aquisitivo entre eles e os assaltantes atribui a eles, as vítimas dos assaltos, o maior status. Qual o trabalho que esta autodeclaração realiza então no plano subjetivo? 
Em seu clássico estudo sobre a dádiva, Mauss (2003) realiza, em meio a uma profusão de dados etnográficos, uma análise do ritual do potlatch, encontrado entre as tribos do noroeste norte-americano. No potlatch, enormes quantidades de riquezas materiais são destruídas, em um esforço de construção de prestígio social e obtenção de poder por meio do desprendimento material: se eu destruo, é porque posso dispor, e se destruo mais, é porque tenho mais, e por isso posso mais e sou mais. Os entrevistados, assim, ao rirem de uma suposição quanto à própria destituição, recolocamse em uma posição de superioridade hierárquica. "Tenho tão mais do que você e estou tão seguro disto que sequer preciso ostentar, sequer me deixo atingir pela sua suposição de que tenho pouco": é isto que os entrevistados parecem estar realizando no plano da linguagem, em uma espécie de potlatch discursivo.

Úrsula sintetiza esse "clima" geral dizendo não reagir porque, ao contrário dos assaltantes, precisa zelar por sua vida porque tem o que perder: "E eu não reajo a assaltos porque eu acho que eu tenho muito a perder. Eles não têm a perder, né?".

Estes comentários, aliados àqueles sobre a "ignorância" dos assaltantes, sugerem a recorrência de um sentimento de desprezo a eles dirigido pelas vítimas. Em estudo sobre os sentimentos de nojo e desprezo, Miller (1997) os define como "emoções de demarcação de status". Falando especificamente sobre o desprezo, Miller o identifica como um mecanismo capaz tanto de criar quanto de contestar hierarquias, residindo aí sua importância política. O autor expõe assim sua visão sobre a capacidade micropolítica do desprezo:

O desprezo é o complexo emocional que articula e mantém a hierarquia, o status, a classificação e a respeitabilidade. E status e classificações diferenciados são as condições que suscitam o desprezo. Assim, o que temos é uma espécie de círculo vicioso no qual o desprezo ajuda a criar e manter as estruturas que geram a capacidade do desprezo. E há boas razões para se acreditar que o estilo específico de desprezo estará intimamente ligado aos arranjos sociais e políticos particulares nos quais ele se dá (Miller 1997:217, tradução minha).

Com base nesta análise de Miller (1997) sobre a capacidade do desprezo de demarcar hierarquia, podemos então apontar um primeiro traço da dinâmica emocional que marca as experiências de vitimização aqui analisadas: o esforço de recuperação, por meio deste sentimento, de um lugar de superioridade hierárquica no plano subjetivo.

O desprezo, contudo, não é o único sentimento capaz de realizar este trabalho. A compaixão é um sentimento dotado também desta mesma capa- 
cidade micropolítica (Clark 1997), e está presente em algumas passagens destes relatos, como neste trecho da fala de Vânia:

Você fica chocada na hora, tem pena daqui, dali, mas nada de me afetar.

Você tem pena desses caras que te assaltaram, não? O que você sente em relação a eles?

Bom, você na hora fica revoltada, né? Meu marido dizia assim: "Eu quero guardar bem a cara deles, se algum deles sair, chegar lá no hospital, eu falo lá: 'Ó! Dá um jeito aí!'". Quer dizer, ele, mas eu também; na hora, eu também acho que eu falo. Na hora eu fico. Eu tenho pena realmente, porque são uns pobres coitados, eles são um... pessoal que não tem... Eu acho que eles não têm amor. Falta um amor total aí. Então, é um pessoal que não tem nada. E eles não têm nem nada a perder, nem a vida, porque eles estão se arriscando mesmo e não têm medo de nada (Vânia).

O depoimento de Úrsula introduz explicitamente ainda outro sentimento que aparece de forma velada nos demais: a impotência, à qual a entrevistada faz menção em várias passagens. Seu relato estabelece em vários trechos relações entre a impotência, o medo, a raiva e a pena:

Olha, um era bem alto, entendeu? E ele falava - esse que eu fui pro closet com ele, que foi o que ameaçou a gente o tempo todo, o tal das armas, que caiu a bala e ficou procurando - ele era pardo, sabe? Alto. Ele falou que tava em liberdade condicional, que tava roubando pra comer, entendeu? Que ele tinha uma filha de quatro meses e que ele não tinha dinheiro, que ele tinha tentado arrumar emprego, mas quando souberam que ele era ex-presidiário, tinham mandado ele embora, que ele tava roubando pra comer. O outro... [...] Não, esse eu fiquei com pena, a gente fica com pena, né?

Esse que tava comigo no hall, no closet... E quando ele saiu, fez um monte de ameaças... Ele ficou olhando assim pra mim: "Você vai ver! não sei o quê...". Sabe? Essas coisas. Aí você fica assustada, até porque... você fica com um sentimento assim, é uma pena misturada com medo, entendeu? E com impotência, porque você vê o cara, ele entrou ali, o que ele vai fazer ali?

Agora na hora, eu não fiquei com raiva, entendeu? Assim, tem gente que fala: "Ah! Você não ficou com raiva? Vontade de pegar uma arma e matar todo mundo?". Eu não faço isso. Eu não tive esse sentimento. Eu fiquei muito mais com uma coisa de pena. Até a tenente falou pra mim: "Eu não acredito que a senhora disse isso. Porque a senhora está inocentando o pretinho!". Eu falei: "Mas eu não posso mentir perante a juíza!". Ainda falei: "Olha a mãe dele ali! 
Vê se você não tem pena dessa criatura?!" O que levou a ela? Porque isso aí, no fundo se o filho tem um mau caminho né? Que é ou viciado em droga ou qualquer, ou de classe rica, ou pobre, a culpa é sempre da família. Porque a família não soube, sabe? Faltou alguma coisa ali, entendeu? Porque não é possível que a pessoa nasça com uma índole ruim.

Nos dois primeiros fragmentos, a pena aparece como uma decorrência do medo e da impotência diante das ameaças recebidas; no terceiro, a pena surge como alternativa à raiva passível de ser suscitada pelas ameaças. Neste caso, a lógica que orienta esta dinâmica emocional é uma concepção das causas do comportamento do agressor que seriam extrínsecas à sua decisão consciente (a sua "índole"). Clark (1997) comenta sobre a existência nos Estados Unidos contemporâneos de uma "sociologização" das concepções de responsabilidade do sujeito pelas próprias ações, eximindo-o de culpa em função de condicionamentos de ordem "macro" que o constituiriam. ${ }^{5}$ É esta a lógica que parece orientar o relato de Úrsula: a "culpa" nunca é do sujeito, mas sempre do ambiente social que o constituiria e conformaria suas ações.

Um último depoimento vem reforçar essa presença da pena como um aspecto emocional relevante dessas experiências de vitimização. Joana, ao terminarmos a entrevista e já com o gravador desligado, comentou que até o assalto vivia "anestesiada", sem "ver as pessoas". Após o assalto, passou a sentir "pena" delas.

Em seu discurso, ela não nomeia quem seriam essas pessoas invisíveis, as quais, ao serem notadas, nela suscitaram pena. Só podemos entender quem são através de suas associações, quando, na sequência da conversa, ela conta o caso de uma pessoa a quem encontra por acaso e que ela jamais havia notado ter trabalhado em sua casa como faxineira, arrematando: "para mim, ela era só um detalhe na minha vida". ${ }^{6}$

Aquela associação entre violência e pobreza com que principiei a análise dos depoimentos, com sua conexão com as diferenças entre classes sociais, reaparece aqui com este matiz emocional: este "outro" que a agride é o mesmo "outro" que lhe presta serviços, e a quem, ao notá-lo, passa a destinar, em lugar da indiferença, um sentimento de pena por sua condição, estabelecendo neste movimento uma hierarquia em que ela, a entrevistada, ocupa a posição de maior status.

A "pena" de Joana parece executar assim aquele trabalho micropolítico que, ainda segundo Clark (1997), estaria entre as capacidades micropolíticas da compaixão: a demarcação de fronteiras entre grupos sociais. Para Clark, a compaixão é um sentimento assimétrico que, ao mesmo tempo em que é 
facultado pela ocupação de lugares socialmente distintos, concorre por sua vez para assinalar e reforçar essa assimetria entre aquele que dá e aquele que recebe a compaixão. É este caráter assimétrico da compaixão que a conduz à reflexão sobre a "micropolítica emocional":

Mesmo quando aqueles que se compadecem não têm a intenção consciente de fazê-lo, compadecer-se pode ter consequências micropolíticas. Ironicamente, trocar compaixão na economia socioemocional pode aproximar as pessoas e ao mesmo tempo aprofundar o abismo social entre elas (:228, tradução minha).

Esta percepção de estar diante de um "outro" de natureza distinta da sua é cristalina na fala que Úrsula atribui a seu marido, endereçada a um assaltante, em um esforço para convencê-lo de que não tinha armas ou bens de grande valor: "A gente é do bem, cara! A gente não tem nada aqui! Eu nunca fiz mal a ninguém! Eu sou médico! Eu trato de gente igual a você!".

E, portanto, diferente dele.

\section{Conclusão}

A análise dos depoimentos revelou a existência de um conjunto de sentimentos que se articulam entre si formando dinâmicas emocionais capazes de realizar diversos "trabalhos". É assim que essas experiências de vitimização suscitam nos entrevistados, em um primeiro plano, humilhação, medo e/ou impotência, os quais podem fluir, ao menos em tese, por um de três "canais": a raiva, o desprezo ou a compaixão. Como explicar a recorrência, entre os entrevistados, desta dinâmica emocional particular?

Em sua análise da dinâmica emocional que engendra os chamados "crimes hediondos" (um pai que espanca seu bebê porque este não obedece às ordens para que pare de chorar, ou um homem que mata seu vizinho por obstruir a entrada de sua garagem), Katz (1988), com base em uma perspectiva interacionista, formula a hipótese de que as atitudes da vítima foram interpretadas pelos agressores, naquela situação, como um desafio a um "bem moral" essencial para o modo como se viam, provocando com isso uma espécie de "ira santa". Assim, o bebê que não para de chorar desafia a autoridade paterna; o vizinho que obstrui a entrada da garagem ameaça o direito à propriedade; ou ainda o marido que queima os livros da esposa e atrapalha seus estudos desrespeita os direitos da mulher.

Em todas essas cenas, Katz identifica uma dinâmica emocional que inicia com um sentimento de humilhação "holístico", ou seja, algo que toma 
conta do agressor e que coloca em xeque sua autoimagem, parecendo-lhe, naquele momento, ser eterno. A raiva decorreria da necessidade fundamental de salvaguardar essa autoimagem, funcionando assim como um "contraponto" da humilhação e motivando uma agressão que se, por um lado, não visa necessariamente à morte do agressor (podendo ser freada por uma mudança de atitude, como um pedido de desculpas, por exemplo), por outro, não se contenta com ela (podendo ter prosseguimento com a imposição de novas agressões ao corpo da vítima). Estaríamos assim diante de um complexo emocional humilhação-raiva, cuja lógica seria a defesa de certa moralidade percebida pelo agressor como essencial para sua identidade.

A dinâmica emocional encontrada nos relatos aqui analisados pode ser mais bem compreendida se contrastada com aquela identificada por Katz em seu universo de análise. A tradução empírica da raiva em uma reação ou agressão ao assaltante é, na percepção da situação pelos entrevistados, indesejável, na medida em que passível de colocar em risco sua integridade física e/ou de seus cônjuges, parentes, amigos, empregados. Aquela dinâmica emocional descrita por Katz (1988) de transformação da humilhação em raiva parece então ser um canal vedado a estes entrevistados.

Mas as agressões analisadas por Katz não são meramente ações de natureza instrumental: são principalmente ações expressivas, através das quais os agressores pretendem estar resgatando sua autoestima e restabelecendo valores morais entendidos como bens supremos, constitutivos de sua identidade e visão de mundo. Que fazer, então, quando a definição da situação parece, aos olhos do narrador, inviabilizar este curso de ação?

A hipótese que proponho aqui é a de que desprezo e compaixão se apresentam como sentimentos capazes de realizar, no plano emocional, o mesmo trabalho que a agressão física: em sua capacidade micropolítica, desprezo e compaixão restabeleceriam a hierarquia ameaçada pela invasão das casas, pela expropriação de bens, pelos xingamentos e ameaças, pelas eventuais agressões físicas. Estes sentimentos, contudo, fazem ainda mais: articulados a uma representação dos assaltantes como "desordeiros", "pobres" e "ignorantes", o desprezo e a compaixão sugerem estarmos diante de uma percepção da violência urbana como associada a diferenças entre classes sociais, entendidas em termos de poder aquisitivo e/ou local de moradia. E é justamente a hierarquia entre estas duas "classes sociais" distintas - às quais pertenceriam "assaltante" e "vítima" — invertida pela violência, que estes sentimentos buscariam assim restabelecer.

Humilhação, medo e impotência formam então, juntamente com a raiva, o desprezo e a compaixão, um complexo emocional dotado de uma dinâmica específica dessas situações de vitimização, capaz de nos fornecer um guia 
para a compreensão da experiência subjetiva associada a certa percepção da violência. ${ }^{7}$ Este complexo emocional executaria um trabalho subjetivo de restauração de uma hierarquia que, na visão dos entrevistados, a condição de vítimas teria abalado, evidenciando assim a existência de uma relação entre gramáticas emocionais, relações interpessoais e organização social.

Esta forma de análise da experiência da vitimização pretende assim concorrer para o aprofundamento do problema teórico fundamental do projeto de que este artigo é resultado: os limites e as possibilidades de construção das emoções como objeto da análise socioantropológica, aqui explorados por intermédio de sua capacidade micropolítica, em seu potencial para servir de via de acesso ao estudo de temas nobres e canônicos da agenda das ciências sociais, como a violência urbana.

Recebido em 02 de junho de 2010

Aprovado em 08 de agosto de 2010

Maria Claudia Coelho é antropóloga, professora do PPCIS/UERJ. E-mail: <mccoelho@bighost.com.br>

\section{Notas}

* Este artigo traz resultados parciais do projeto intitulado "Moral, alteridade e sentimentos: percepções da violência", desenvolvido no âmbito do PROCIÊNCIA da UERJ. Uma primeira versão deste trabalho foi apresentada no $33^{\circ}$. Encontro da ANPOCS (Caxambu, outubro de 2009).

${ }^{1}$ Os maridos destas entrevistadas não aceitaram dar entrevistas.

${ }^{2}$ Em outros trabalhos, realizamos esforços mais detalhados de mapeamento desta história do campo da antropologia das emoções na cena norte-americana (Rezende \& Coelho 2010; Coelho \& Rezende, no prelo).

${ }^{3}$ Como de praxe, os nomes dos entrevistados são fictícios.

${ }^{4}$ Este traço da estrutura narrativa dos relatos sobre vitimização aparece também em meus depoimentos, conforme comentei em outro lugar (Coelho 2006). 
${ }^{5}$ O tema da relação entre a concepção da responsabilidade do sujeito pelo infortúnio e a emergência da compaixão está presente também em análises deste sentimento em outros contextos históricos e culturais, como na discussão de French (1994) sobre a atitude de refugiados em campos no Cambodja diante daqueles que sofreram amputações em decorrência de acidentes com minas.

${ }^{6}$ Este depoimento de Joana ilustra com particular poder de síntese aquele diagnóstico discutido por Soares acerca da "invisibilidade" que caracterizaria as relações entre os dois lados da "cidade partida" (Ventura 1994) em que o Rio de Janeiro se teria tornado: "os 'de baixo' são frequentemente invisíveis para os de cima, salvo quando lhes metem medo, produzem incômodo ou passam a representar alguma ameaça, imaginária ou real" (Soares 2000:41).

${ }^{7}$ Em outros trabalhos, explorei diferentes dinâmicas emocionais associadas a formas de percepção da violência, tais como a dinâmica humilhação-coragem associada a uma concepção da violência como desamparo (Coelho 2009a), a tríade raivacalma-medo e sua articulação com o gênero (Coelho 2006, 2009b) e o papel da calma como estratégia discursiva de apaziguamento do sujeito (Coelho \& Santos 2007).

\section{Referências bibliográficas}

CALDEIRA, Teresa. 2000. Cidade de muros crime, segregação e cidadania em São Paulo. São Paulo: Editora 34/EDUSP.

CLARK, Candace. 1997. Misery and company - sympathy in everyday life. Chicago \& London: The University of Chicago Press.

COELHO, Maria Claudia. 2006. "Emoção, gênero e violência: experiências e relatos de vitimização". RBSE, 5(13):36-53.

. 2009a. "Lágrimas com farinha: percepções femininas da violência em Belém do Pará". In: J. T. Sento-Sé (org.), Segurança pública — outros olhares, novas possibilidades. Brasília: SPM. pp. 119-135.

. 2009b. "Gênero e vitimização: percepções sobre a violência urbana no
Rio de Janeiro". Trabalho apresentado na VIII Reunião de Antropologia do Mercosul, Buenos Aires, Argentina.

. \& REZENDE, Claudia Barcellos (no prelo). Cultura e sentimentos - ensaios em antropologia das emoções. Rio de Janeiro: FAPERJ/Contra Capa. . \& SANTOS, Raphael Bispo dos. 2007. "Emoção e experiências de vitimização: notas sobre a micropolítica das emoções". In: Anais da VII Reunião de Antropologia do Mercosul, Porto Alegre, Rio Grande do Sul.

DOUGLAS, Mary. 1976. Pureza e perigo. São Paulo: Perspectiva.

FRENCH, Lindsay. 1994. "The political economy of injury and compassion: amputees on the Thai-Cambodia bor- 
der". In: T. Csordas (org.), Embodiment and experience. Cambridge: Cambridge University Press. pp. 69-99.

KATZ, Jack. 1988. Seductions of crime. New York: Basic Books.

LUTZ, Catherine. 1988. Unnatural emotions: everyday sentiments on a Micronesian atoll and their challenge to Western theory. Chicago: University of Chicago Press.

. 1990. "Engendered emotion: gender, power, and the rethoric of emotional control in american discourse". In: C. Lutz \& L. Abu-Lughod (orgs.), Language and the politics of emotion. Cambridge: Cambridge University Press. pp. 69-91.

. \& ABU-LUGHOD, Lila (orgs.). 1990. Language and the politics of emotion. Cambridge: Cambridge University Press.

MAUSS, Marcel. 2003. "Ensaio sobre a dádiva". In: Sociologia e antropologia. São Paulo: Cosac Naify. pp. 183-314.

MILLER, William Ian. 1997. The anatomy of disgust. Cambridge: Harvard University Press.

REZENDE, Claudia Barcellos \& COELHO, Maria Claudia. 2010. Antropologia das emoções. Rio de Janeiro: Editora da Fundação Getúlio Vargas.

ROSALDO, Michelle. 1984. "Toward an anthropology of self and feeling". In: R. Shweder \& R. LeVine (orgs.), Culture theory - essays on mind, self and emotion. Cambridge: Cambridge University Press. pp. 137-157.

SOARES, Luiz Eduardo. 2000. Meu casaco de general - 500 dias no front da segurança pública no Rio de Janeiro. São Paulo: Companhia das Letras. . \& CARNEIRO, Leandro Piquet. 1996. "Os quatro nomes da violência: um estudo sobre éticas populares e cul- tura política". In: L. E. Soares et alli. Violência e política no Rio de Janeiro. Rio de Janeiro: Relume-Dumará/ ISER. pp. 13-57.

TAUSSIG, Michael. 1984. "Culture of Terror - Space of Death. Roger Casement's Putumayo Report and the Explanation of Torture". Comparative Studies in Society and History, 26: 467-97.

VENTURA, Zuenir. 1994. Cidade partida. São Paulo: Cia. das Letras. 
Resumo

Este trabalho tem por objetivo examinar as emoções presentes em relatos de experiências de vitimização em segmentos das camadas médias do Rio de Janeiro. A proposta é explorar a fecundidade da vertente "contextualista" (Lutz \& AbuLughod 1990) da antropologia das emoções para a compreensão da violência, com foco na dimensão micropolítica dos discursos sobre as emoções ligadas à vitimização. Os dados analisados são um conjunto de oito entrevistas em profundidade realizadas com casais que passaram, marido e mulher, pela experiência de terem suas residências assaltadas enquanto estavam em casa. A análise está focada na recorrência de duas emoções presentes nas descrições que os entrevistados fazem de seus sentimentos em relação aos assaltantes: compaixão e desprezo. A emergência destas duas emoções, cujas relações com a hierarquia já foram apontadas pelas ciências sociais, é então interpretada como uma tentativa de restabelecer hierarquias que teriam sido ameaçadas pelos assaltos.

Palavras-chave Emoção, Micropolítica das emoções, Violência urbana, Desprezo, Compaixão.

\section{Abstract}

This paper analyzes the emotions described in narratives of victimization among Rio de Janeiro's middle classes. It explores the so-called 'contextualist' trend (Lutz \& Abu-Lughod 1990) in the anthropology of emotions as a means to understanding violence, focusing on the micropolitical dimension of emotion discourses on victimization. The data analyzed is derived from eight in-depth interviews with married couples who have been through the experience of having their residences assaulted while both of them were at home. The analysis focuses on the recurrence of two emotions in the interviewees' depictions of their feelings towards their assailants: sympathy and contempt. The emergence of these two emotions, whose relations to hierarchy have already been well documented by social scientists, is interpreted as an attempt to re-establish the hierarchies perceived to have been overturned by the assaults.

Key words Emotion, Micropolitics of Emotion, Urban Violence, Contempt, Sympathy. 